\title{
Unequal Social Protection under the Federalist System: Three Unemployment Insurance Approaches in the United States, 2007-2015
}

\author{
CHANG YU-LING 10 \\ School of Social Welfare, University of California, 120 Haviland Hall MC 7400, Berkeley, \\ CA 94720-7400, USA \\ email: ylchang@berkeley.edu
}

\begin{abstract}
Despite the increased attention paid to federal-state unemployment insurance (UI) schemes after the Great Recession (2007-2009), research examining the policy characteristics and the underlying logic shaping the social protection provided by a federal-state UI system is limited. Integrating the perspectives of policy design theory, comparative welfare politics, and fiscal welfare, this paper examines the unequal social protection under the American UI system during and after the Great Recession. By using model-based cluster analysis and fixed-effect panel regression models, this paper identifies three distinct UI approaches, i.e. the limited social protection approach, the unbalanced social protection approach, and the balanced social protection approach. The policy choices made by those states that follow the three approaches reflect different mixtures of policy logic, including social protection, economic stabilization, work disincentives, and interstate competition. The overall downward trend in social protection signals that the American UI system is under-prepared for the next economic recession, thereby exposing unemployed workers to the risk of economic insecurity. These findings provide implications for future policy designs aiming to strengthen the social protection of the federal-state UI system.
\end{abstract}

Keywords: unemployment insurance; social protection; Great Recession; comparison research; model-based cluster analysis; federalist

\section{Introduction}

Unemployment insurance (UI) has been a vital part of the social protection for working families in contemporary welfare states since the early 190os, when the United Kingdom launched the first nationwide UI system under the National Insurance Act of 1911 (Orloff and Skocpol, 1984). UI provides wage replacements to workers to compensate for their income losses during a job transition. UI's essential role in social protection has generated substantial scholarly interest in examining the cross-national similarities and differences in the designs and performance of UI systems (e.g. Arcanjo, 2012; Esser et al., 2013; 
Gallie and Paugam, 2000; Ozkan, 2014; Shahidi, 2015; Vroman and Brusentsev, 2005). However, most previous comparative studies have limited their analyses of social protection to the inclusiveness and generosity of UI provisions. Social policy scholars have argued that the fiscal structure of social insurance (e.g. taxes and trust funds) is also central for an understanding of the distributive outcomes in a society, particularly when welfare spending is restricted due to scarce public resources at a time of an economic recession (Koreh, 2017; Sinfield, 2018).

The global Great Recession in the late 2000 s challenged the UI systems in industrialized countries in providing responsive and adequate protection for unemployed workers (Chang, 2015; Shahidi, 2015). In the wake of the Great Recession, a central UI policy debate among the European Union (EU) member states has involved the establishment of a supranational European unemployment benefits scheme (EUBS) as a Europe-wide stabilization and redistribution mechanism (Andor, 2016; Davis et al., 2015; Esser et al., 2013). Policy discussions have centred more on the issues regarding economic stabilization and moral hazard than the issues regarding social protection and solidarity among the varying welfare traditions. The harmonization of different national UI systems could be a major challenge in designing a EUBS (Andor, 2016; Beblavý et al., 2015). To inform the design of a EUBS, policy researchers have recently sought to explore the experience with the American federal-state system (Lenaerts et al., 2017; O’Leary and Barnow, 2016).

The American welfare state represents a liberal, residual, reluctant regime of welfare states that typically provide minimal social protection to their citizens (Esping-Andersen, 1990). According to OECD statistics (OECD, 2017), the net replacement rate of unemployment benefits in 2013 in the US was $26 \%$ relative to the average of $39 \%$ among European countries. In contrast to the centralised UI systems in other advanced countries, American UI operates through a hybrid federal-state system in which the responsibilities of the programme design are shared between the federal government and the states (Shaefer, 2010; Vroman, 2012). The subnational variations in design and performance across fifty-three programmes provide an empirical ground for studying the different UI approaches to social protection and their underlying policy logic.

Motivated by the increased attention paid to the federal-state design of UI systems, this paper addresses the following three questions: (1) What are the features of the American federal-state UI system? (2) Are there distinct UI approaches to social protection that differ in the patterns of their policy design and performance in the dimensions of financing, eligibility, and benefit? (3) If so, how do different types of policy logic relate to political and economic conditions to explain the approaches taken by states and their policy changes during and after the Great Recession? 
This paper contributes to the UI comparison literature in two ways. Conceptually, it integrates the perspectives of policy design theory (Ingram et al., 2007; Schneider and Ingram, 1988, 1997), comparative welfare politics (Allan and Scruggs, 2004; Scruggs and Allan, 2008), and fiscal welfare (Koreh, 2017; Sinfield, 2018) into a framework for studying UI approaches. This framework emphasizes that both financing and social provision arrangements define different UI approaches to social protection. These approaches reflect different mixtures of four policy logics, i.e. social protection, economic stabilization, work disincentives, and interstate competition, which are subject to political and macroeconomic contexts. Empirically, this research used the model-based clustering method and analysis of variance (ANOVA) to identify three distinct UI approaches and established panel regression models to explain the changes in social protection and their underlying policy logic during the 2007-2015 period according to the approach.

The results show that states that followed the limited social protection approach (featured by low social provision and financing) tended to operate their UI systems through the logic of market stabilization, the logic of work disincentives, and the logic of interstate competition in the context of a highly and increasing conservative ideology. In contrast, states that followed the balanced social protection approach (featured by high social provision and financing) tended to operate their UI systems through the logic of social protection and the logic of market stabilization in response to the economic cycle and the needs of unemployed workers. The remaining states that followed the unbalanced social protection approach (featured by medium social provision and low financing) tended to make uncoordinated policy choices reflecting the tensions among concerns regarding social protection, market stabilization, and work disincentives in response to the economic cycle and an increasing conservative ideology. This paper provides policy implications for future designs and reforms of the federal-state UI system.

\section{A conceptual framework for studying unemployment insurance approaches to social protection}

Comparative welfare scholars have analysed different welfare systems and related them to various types of political economy (Esping-Andersen, 1990; Scruggs and Allan, 2008). UI studies following this line of scholarship have focused on comparing key programme arrangements for social provision and the size of programme expenditure as a percent of the GDP as key indicators of social protection (Gallie and Paugam, 2000; Ozkan, 2014); however, the financing structures of UI programmes are overlooked. Social insurance programmes not only allocate social provision by designing and implementing eligibility and benefit rules but also collect taxes on contributions from individuals 
Unemployment Insurance Approaches to Social Protection

(Ways to design and implement UI that have interrelated elements working as unified systems to achieve social protection)

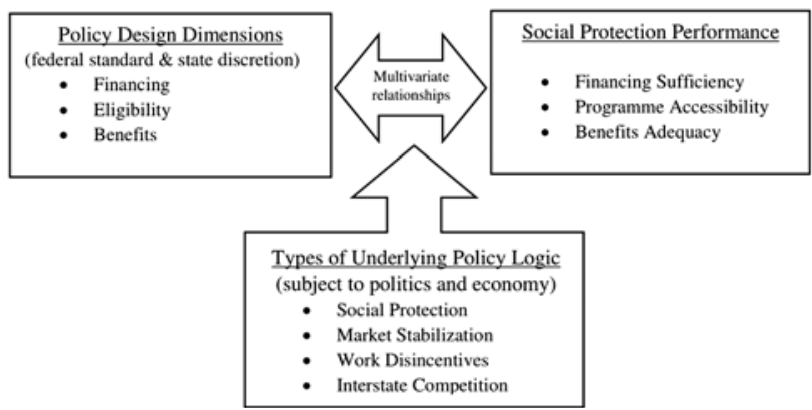

Figure 1. Conceptual framework for studying UI approaches to social protection.

and/or employers to build trust funds that support such provisions (Koreh, 2017). Therefore, a more comprehensive understanding of social protection should consider both financing and social provision arrangements.

Drawing on the policy design theory (Ingram et al., 2007; Schneider and Ingram, 1988, 1997) and the prior UI literature, I propose a conceptual framework for studying UI policy approaches to social protection, which are defined as ways to design and implement UI programmes with interrelated elements that work as a unified system to achieve social protection. Underlying these UI approaches are different policy logics, subject to the political and economic contexts. As presented in Figure 1, the top of this framework shows that UI systems comprise policy designs of financing, eligibility, and benefit arrangements. Each dimension has the potential to enhance social protection by ensuring financing sufficiency, programme accessibility, and benefit adequacy. It is anticipated to see variations in UI approaches that differ by the level of financing sufficiency, programme accessibility, and benefit adequacy. The two-directional arrow indicates that, on the one hand, policy design elements contribute to policy performance, and, on the other hand, policy performance also informs future policy designs through a policy feedback loop (Schneider and Ingram, $1988,1997)$ or a mechanism of path dependence (Pierson, 2000).

The bottom of this framework shows the different types of policy logic that relate to the political or economic conditions that influence the social protection provided by different UI approaches. First, the logic of social protection emphasizes preventing unemployed workers and their families from suffering income losses due to involuntary unemployment. Policy choices based on this logic emphasize establishing reasonable taxable wage bases and tax rates to adequately fund UI programmes (Vroman, 2012), set eligibility rules that include more jobless workers in the UI system (Lindner and Nichols, 2012), and offer adequate 
benefit amounts and durations to support unemployed workers (Bivens et al., 2014; Kimball and McHugh, 2015). A strong social protection approach that operates with this logic would be featured as high financing sufficiency, high programme accessibility, and high benefit adequacy. According to previous cross-national comparative studies, partisan politics have strongly predicted the welfare state commitments to social protection (Allan and Scruggs, 2004; Esping-Andersen, 1990). Likewise, the research on American welfare politics has shown that the liberal party has been more willing to support public social provision than the conservative party (Hertel-Fernandez, 2013; O'Connor, 2004).

During economic downturns, the logic of market stabilization aligns well with the logic of social protection to justify UI provision and financing adjustments. Keynes' policy prescription for responding to economic downturns, which assumes that government interventions are necessary to resolve economic crises, is the intellectual origin of the logic of market stabilization (Henchman, 2011). Policy choices based on this logic emphasize strengthening the countercyclical mechanism of UI to smooth macroeconomic fluctuations. Examples include accumulating sufficient state trust funds during economic booms to avoid insolvency during recessions and distributing UI benefits efficiently and adequately to stimulate a depressed economy (Vroman, 2010, 2012).

Policy choices based on the logic of work disincentives often counter policy choices based on the logic of social protection, which emphasizes individual obligations over social rights (Arcanjo, 2012). Conservatives have often criticized UI for a moral hazard problem that creates a work disincentive and perpetuates long-term unemployment (Tatsiramos and Ours, 2014). Therefore, it is expected that right-oriented governments are more likely to support policy designs involving demands and conditionality (e.g. job search activities) than left-oriented governments (Fossati, 2018; Henchman, 2011).

Finally, the logic of interstate competition assumes that states will lose their economic competitive advantage in relation to their neighbouring states if they impose higher tax burdens on employers or distribute more generous benefits to the unemployed (Pierson, 1995). Therefore, state policymakers favour limited UI taxes and benefits to build a favourable investment environment for economic growth and to avoid becoming a welfare magnet state. The logic of interstate competition would be evident if states reduced their tax rates or benefit levels when their tax rates or benefit levels were higher than their neighbouring states.

States' UI policy approaches may reflect a mixture of different types of policy logic, subject to states' economic and political conditions. To understand different UI approaches to social protection, a comparative study with a multivariate analysis that includes policy design elements, policy performance, and contextual variables is warranted. The measures of relevant variables and the procedures of multivariate analysis are described in the following method section. 


\section{Methods}

\section{Data sources and measures}

I retrieved the UI policy data from the following three sources available on the United States Department of Labor website: (1) the Unemployment Insurance Data Summary; (2) the Significant Provisions of State UI Laws; and (3) the Comparison of State UI Laws. This research used ten measures of UI design and performance that were grouped by their most relevant dimensions (i.e. financing, eligibility, and benefits) as follows. Additional explanatory variables were used to analyse the policy logic that underlies different UI approaches. My observations included the 50 states and the District of Columbia (collectively referred to as the 51 states).

\section{Financing variables}

Taxable Wage Base referred to the maximum amount of wages paid to a worker, during a tax year, that were subject to UI taxes (U.S. Department of Labor, 2015a). This variable was measured in dollars with a minimum value of $\$ 7,000$. Average Tax Rate was measured by the total employer contributions as a percentage of the total taxable wages in the past 12 months (U.S. Department of Labor, 2015a). Reserve Ratio represented a state's trust fund balance as a percentage of the total wages paid in the past 12 months (U.S. Department of Labor, 2015a). A higher value indicated higher UI financing sufficiency.

\section{Eligibility variables}

Qualifying Wage was measured by the minimum amount of wages needed to qualify for UI during the base period (U.S. Department of Labor, 2015b). Annual Regional Price Parities (RPPs, published by the Economic Analysis Bureau) were applied to adjust for the states' cost-of-living standards. A lower qualifying wage suggested more lenient momentary eligibility. Eligibility Modernization was measured on a synthesized o-to-4-point scale that transformed the adoption of several dichotomous provisions into a single continuous eligibility modernization value. ${ }^{1}$ This measure captured the non-momentary eligibility rules, which might be key barriers to UI access among disadvantaged workers (Shaefer, 2010). The Recipiency Rate was defined as the insured unemployed in the regular UI programme as a percentage of the total unemployed over the most recent 12 months (U.S. Department of Labor, 2015a). A higher value suggested a higher level of UI accessibility.

\section{Benefits variables}

Average Weekly Benefit Amount was calculated by the total wages divided by covered employment divided by 52 weeks (U.S. Department of Labor, $2015 \mathrm{C})$. This value was then adjusted for the states' cost-of-living standards. 
Replacement rate was defined as the average weekly benefit amount as a percentage of the average weekly wage (U.S. Department of Labor, 2015C). A higher value suggested a higher level of benefit adequacy. Maximum Benefit Duration referred to the maximum number of weeks of regular state UI benefits available to recipients (U.S. Department of Labor, 2015d). The Exhaustion Rate was measured by the average monthly exhaustions (the numbers of claimants drawing their final payments) during the past 12 months as a percentage of the average first monthly payments during the past 7 to 18 months (U.S. Department of Labor, 2015a). A higher value indicated that recipients are more likely to use up their benefits before transitioning back to work.

\section{Explanatory variables}

State government ideology was a o-100 score that measured the conservative-liberal ideology developed by Berry et al. (2010). A higher score indicated a more liberal state government. Macroeconomic condition was captured by the state annual unemployment rate. Interstate competition-tax (or benefit) was measured by a ratio of the tax rate (or the average weekly benefit) of a state relative to the average tax rate (or the average weekly benefit) of its neighbouring states. A higher value indicated a stronger pressure of interstate competition for a lower tax rate or a lower level of benefit generosity.

\section{Analytic procedure}

To answer the first research question regarding the features of the American federal-state UI system, I documented the key UI features and analysed the ten UI policy indicators across 51 states during the 2007-2015 period. ${ }^{2}$

To address the second question concerning the distinct UI approaches to social protection, I conducted a cluster analysis of nine ${ }^{3}$ policy variables over the study period to classify the states into a small number of homogeneous groups. Each yearly UI policy variable was first transformed to a standardized Z-score with a mean of $o$ and a standard deviation of 1 to avoid the problem that absolute variations might distort the cluster analysis results due to different measurements among the variables. I adopted a model-based clustering technique that overcomes the weakness of conventional agglomerative hierarchical clustering and K-means clustering in selecting the optimal number of clusters (see detailed discussion in Ahlquist and Breunig, 2012). The model-based cluster analysis was performed by using mclust version 4 in R (Fraley et al., 2012), which permitted an evaluation of the probability of each state's cluster assignment. To determine the final solution that most closely fit the observed data, I examined the Bayesian information criterion (BIC) ${ }^{4}$ values for two to ten cluster solutions in combination with 14 different model assumptions to determine the volume, shape, and orientation of the clusters. Then, I conducted an ANOVA to test the significant 
differences in the cluster-level mean of each policy indicator among the identified clusters.

Finally, to answer the third question regarding the relationship between different types of policy logic and political and economic conditions to explain the approaches taken by the states during and after the Great Recession, I first analysed the trends in social protection both at the national level and by approach during the 2007-2015 period. Then, I conducted a series of panel regression models with state fixed effects and robust standard errors to test the policy logic used by the states that followed different approaches (see the results section for detailed explanations of regression models 1-5 in Table 3). All outcome variables were modelled with one-year policy lags of the explanatory variables.

\section{Results}

\section{Features of the American federal-state UI system}

This section presents the features of the American UI system in the dimensions of financing, eligibility, and benefit arrangements. Regarding the financing arrangements, the American system is financed by a two-tier Unemployment Trust Fund that collects federal and state taxes on employers. ${ }^{5}$ The federal trust fund supports the UI administrative expenditures and other related worksupport programmes, and each state's UI trust fund pays benefits to the unemployed workers in the state. The federal government allows the states to establish their own taxable wage bases and tax rates with a minimum standard of $\$ 7,000$ to set the taxable wage base and a mandated experience rating to determine the tax rates. Through the experience rating, a unique design of the American system, employers are encouraged to maintain a stable workforce and are discouraged from laying off too many workers (Whittaker and Isaacs, 2012). The state-level differences in the taxable wage $(\min .=\$ 7,000, \max .=\$ 41,700$ in 2015$)$ and the average tax rate $(\min .=0.88, \max .=6.18$ in 2015 ) contributed to the wide variation in state UI trust fund reserves, which ranged from a zero reserve ratio in California to 4.13 in Oregon in 2015 (Table 1).

Regarding the eligibility arrangements, an unemployed worker must meet both monetary and non-monetary criteria to qualify for benefits. First, an unemployed worker must earn the qualifying wage during the standard base period, which is typically defined as the first four of the last five completed calendar quarters prior to unemployment. The level of qualifying wages varied widely across states even after adjusting the cost of living across states ( $\mathrm{min} .=\$ 109$ in Hawaii, $\max .=\$ 6,096$ in Washington in 2015). For the non-monetary eligibility criteria to qualify for UI benefits, a worker must lose his or her job through no fault of his or her own (typically, a plant closing or a layoff) and must be available for work (typically, a full-time job). The outdated eligibility rules potentially exclude low-wage workers from the UI system because they are more likely to 
TABLE 1. Summary of the descriptive statistics of the UI variables

\begin{tabular}{|c|c|c|c|c|c|}
\hline Variable & Min. & Max. & Mean & Std. Dev. & Cov. \\
\hline \multicolumn{6}{|l|}{ Financing variables } \\
\hline Taxable wage base o7 $(\$)$ & 7000.00 & 32700.00 & 13850.00 & 7866.63 & 0.57 \\
\hline $11(\$)$ & 7000.00 & 37750.00 & 16044.12 & 9168.66 & 0.57 \\
\hline $15(\$)$ & 7000.00 & 41700.00 & 17342.84 & 10188.38 & 0.59 \\
\hline Average tax rate o7 $(\mathrm{o} / \mathrm{o})$ & 0.86 & 5.20 & 2.18 & 0.96 & 0.44 \\
\hline $11(\mathrm{o} / \mathrm{o})$ & 1.14 & 6.05 & 2.92 & 1.05 & 0.36 \\
\hline $15(\mathrm{o} / \mathrm{o})$ & 0.88 & 6.18 & 2.47 & 1.06 & 0.43 \\
\hline Reserve ratio o7 & 0.05 & 3.55 & 1.31 & 1.00 & 0.76 \\
\hline 11 & 0.00 & 2.44 & 0.49 & 0.65 & 1.33 \\
\hline 15 & 0.00 & 4.13 & 1.07 & 0.97 & 0.91 \\
\hline \multicolumn{6}{|l|}{ Eligibility variables } \\
\hline Qualifying wage o7 (\$) & 112.00 & 5523.00 & 2265.90 & 1109.99 & 0.49 \\
\hline $11(\$)$ & 112.00 & 5746.00 & 2423.45 & 1218.66 & 0.5 \\
\hline $15(\$)$ & 109.00 & 6096.00 & $2684 \cdot 31$ & 1319.54 & 0.49 \\
\hline Elig. modernization 07 & 0.00 & 3.75 & 1.43 & 1.14 & 0.8 \\
\hline 11 & 0.00 & 4.00 & 2.63 & 1.35 & 0.51 \\
\hline 15 & 0.00 & 4.00 & 2.68 & 1.38 & 0.52 \\
\hline Recipiency rate o7 (o/o) & 17.41 & 59.01 & $35 \cdot 52$ & 10.31 & 0.29 \\
\hline $11(\mathrm{o} / \mathrm{o})$ & 17.27 & 48.21 & 30.84 & $7 \cdot 73$ & 0.25 \\
\hline $15(\mathrm{o} / \mathrm{o})$ & 12.49 & 56.26 & 28.26 & 10.19 & 0.36 \\
\hline \multicolumn{6}{|l|}{ Benefit variables } \\
\hline Avg. wkly. benefit o7 (\$) & 178.80 & 347.87 & $279 \cdot 34$ & 39.57 & 0.14 \\
\hline $11(\$)$ & 218.35 & 371.82 & 301.70 & $44 \cdot 31$ & 0.15 \\
\hline $15(\$)$ & 189.16 & 501.16 & 321.00 & 59.71 & 0.19 \\
\hline Replacement rate 07 (o/o) & 26.65 & 50.25 & 41.78 & $5 \cdot 51$ & 0.13 \\
\hline $11(\mathrm{o} / \mathrm{o})$ & 28.85 & 51.05 & 42.00 & $5 \cdot 38$ & 0.13 \\
\hline $15(\mathrm{o} / \mathrm{o})$ & 29.40 & 48.95 & 41.02 & 5.43 & 0.13 \\
\hline Max. UI duration o7 (wk) & 26.00 & 30.00 & 26.12 & 0.62 & 0.02 \\
\hline $11(\mathrm{wk})$ & 26.00 & 30.00 & 26.12 & 0.62 & 0.02 \\
\hline 15 (wk) & 15.00 & 30.00 & 25.25 & 2.57 & 0.10 \\
\hline Exhaustion rate $07(\mathrm{o} / \mathrm{o})$ & 11.20 & 54.75 & 32.92 & 8.05 & 0.24 \\
\hline $11(\mathrm{o} / \mathrm{o})$ & $23 \cdot 50$ & 69.10 & 49.07 & 8.57 & 0.17 \\
\hline $15(\mathrm{o} / \mathrm{o})$ & 14.85 & $55 \cdot 50$ & $35 \cdot 38$ & 8.21 & 0.23 \\
\hline
\end{tabular}

Note: 1. Policy variables marked "07" refer to the average of the 2006 and 2007 data; those marked " 11 " refer to the average of the 2010 and 2011 data; and those marked "15" refer to the average of the 2014 and 2015 data.

have short or sporadic work histories (Shaefer and $\mathrm{Wu}, 2011$ ). Historically, only approximately one-third of unemployed workers received regular UI benefits from state programmes (Kimball and McHugh, 2015). To include more lowwage and disadvantaged workers in the UI system, the federal Unemployment Insurance Modernization Act (UIMA) of 2009 provided a total of \$7 billion in incentive funding for states to reform their monetary and non-monetary eligibility rules by August 2011. By the end of the federal intervention, 39 states adopted an alternative base period, i.e. a procedure that recognizes work and earnings not captured during the standard base period allowing low-wage 
workers to more likely meet the monetary eligibility requirement (Gould-Werth and Shaefer, 2013; Shaefer and $\mathrm{Wu}, 2011) ; 26$ states passed the part-time provision that allows claimants to search for part-time jobs, and 19 states allowed compelling family reasons for separation (i.e. domestic violence, spouse relocation, or caring for family members with illness or disabilities) (U.S. Department of Labor, 2011). Given the different eligibility rules across states, the UI recipiency rate ranged from $\mathbf{1 2 . 4 9 \%}$ in Florida to $52.26 \%$ in North Dakota in 2015.

Benefit rules determine how much and how long unemployed workers receive UI benefits. In 2015, the average weekly benefit amount ranged from $\$ 189.16$ in Florida to $\$ 501.16$ in North Dakota. Most states' benefit formulas replaced no more than half of a worker's prior earnings; the replacement rate ranged from $29.40 \%$ in Alaska to $48.95 \%$ in Kansas. In terms of benefit duration, the regular state UI typically offered unemployment benefits for up to 26 weeks in all states (with the exceptions of 28 weeks in Montana and 30 weeks in Massachusetts). Nevertheless, in the aftermath of the Great Recession, nine states decreased their duration of state-funded UI benefits to less than the standard 26 weeks (Kimball and McHugh, 2015). For example, Florida provided the shortest benefit of up to only 14 weeks in 2015 .

Taken together, the wide variations in UI designs and performance across states suggest unequal social protection among American workers, leading to an important research question regarding the distinct state UI approaches to social protection.

\section{Three UI approaches to social protection and their characteristics}

I used nine UI variables with three data points over the 2007-2015 period to classify 51 states' UI programmes. The results of the cluster analysis showed that the two-cluster, ellipsoidal, equal volume, shape and orientation (EEE) model and the three-cluster, EEE model were the top two models $(\mathrm{BIC}=-3,416.43$ and $-3,473.47$, respectively) among 126 models. After examining the posterior probabilities of the state cluster assignments (all between .997 to 1) and the characteristics of the clusters of the top two models, I adopted the three-cluster solution as the final solution because it revealed distinct features in both the social provision and financing characteristics. The three UI clusters are (1) the limited social protection approach, i.e. low provision and financing; (2) the unbalanced social protection approach, i.e. medium provision and low financing; and (3) the balanced social protection approach, i.e. high provision and financing. These approaches were named by interpreting the findings from the ANOVA, Scheffe's tests and descriptive statistics of all policy indicators by approach. Table 2 presents the standardized and unstandardized means of each UI policy variable by cluster. The three-year-average values (columns (4), (8), and (12)) were used to summarize the UI characteristics of the three clusters 
TABLE 2. Cluster-level means by year and mean difference tests

\begin{tabular}{|c|c|c|c|c|c|c|c|c|c|c|c|c|c|c|c|c|}
\hline & & \multicolumn{4}{|c|}{$\begin{array}{c}\text { Limited protection } \\
\text { (low provision and financing) }\end{array}$} & \multicolumn{4}{|c|}{$\begin{array}{l}\text { Unbalanced protection (medium } \\
\text { provision and low financing) }\end{array}$} & \multicolumn{4}{|c|}{$\begin{array}{c}\text { Balanced protection } \\
\text { (high provision and financing) }\end{array}$} & \multicolumn{3}{|c|}{ Scheffe's Tests } \\
\hline & & 2007 & 2011 & 2015 & Average & 2007 & 2011 & 2015 & Average & 2007 & 2011 & 2015 & Average & L vs $\mathrm{U}$ & L vs $B$ & U vs $B$ \\
\hline & & 1 & 2 & 3 & 4 & 5 & 6 & 7 & 8 & 9 & 10 & 11 & 12 & 13 & 14 & 15 \\
\hline \multicolumn{17}{|l|}{ Financing variables } \\
\hline \multirow[t]{2}{*}{ Taxable wage base (\$) } & Mean Z-score & -0.76 & -0.75 & -0.79 & -0.77 & -0.51 & -0.52 & -0.49 & -0.51 & 1.37 & 1.38 & 1.36 & 1.37 & & & \\
\hline & Real mean & 7888.89 & 9188.89 & 9261.11 & 8779.63 & 9840.74 & 11287.04 & 12338.33 & 11155.37 & 24643.33 & 28720 & 31200 & 28187.78 & & $* * *$ & $* * *$ \\
\hline \multirow[t]{2}{*}{ Average tax rate $(\%)$} & Mean Z-score & -0.52 & -0.41 & -0.45 & -0.46 & 0.54 & 0.57 & 0.52 & 0.54 & -0.65 & -0.79 & -0.66 & -0.70 & & & \\
\hline & Real mean & 1.68 & 2.49 & 1.99 & 2.05 & 2.7 & 3.52 & 3.02 & 3.08 & 1.55 & 2.09 & 1.77 & 1.81 & $* *$ & & $* * *$ \\
\hline \multirow[t]{2}{*}{ Reserve ratio } & Mean Z-score & -0.17 & -0.21 & -0.36 & -0.25 & -0.43 & -0.36 & -0.43 & -0.41 & 0.87 & 0.77 & 0.99 & 0.88 & & & \\
\hline & Real mean & 1.14 & 0.35 & 0.72 & 0.74 & 0.89 & 0.26 & 0.65 & 0.6 & 2.18 & 0.99 & 2.04 & 1.74 & & $* *$ & $* * *$ \\
\hline \multicolumn{17}{|l|}{ Eligibility variables } \\
\hline \multirow[t]{2}{*}{ Qualifying wage (\$) } & Mean Z-score & -0.13 & -0.26 & -0.13 & -0.17 & 0.02 & 0.16 & 0.13 & 0.11 & 0.04 & -0.14 & -0.16 & -0.09 & & & \\
\hline & Real mean & 2121.44 & 2111.67 & 2509.56 & 2247.56 & 2287.15 & 2619.85 & 2862.44 & 2589.81 & 2314.33 & 2257 & 2468.53 & 2346.62 & & & \\
\hline \multirow[t]{2}{*}{ Elig. modernization } & Mean Z-score & -0.72 & -1.02 & -1.22 & -0.99 & 0.19 & 0.16 & 0.17 & 0.18 & 0.09 & 0.32 & 0.42 & 0.28 & & & \\
\hline & Real mean & 0.61 & 1.25 & 1 & 0.95 & 1.65 & 2.85 & 2.92 & 2.47 & 1.53 & 3.06 & 3.27 & 2.62 & $* *$ & $* *$ & \\
\hline \multirow[t]{2}{*}{ Recipiency rate (\%) } & Mean Z-score & -0.7 & -0.88 & -1.18 & -0.92 & 0.11 & 0.03 & 0.05 & 0.07 & 0.22 & 0.47 & 0.62 & 0.44 & & & \\
\hline & Real mean & 28.27 & 24.02 & 16.23 & 22.84 & 36.67 & 31.1 & 28.77 & 32.18 & 37.79 & 34.45 & 34.54 & 35.59 & $* *$ & $* *$ & \\
\hline \multicolumn{17}{|l|}{ Benefit variables } \\
\hline \multirow[t]{2}{*}{ Avg. wkly . benefit (\$) } & Mean Z-score & -1.12 & -1.21 & -1.18 & -1.17 & 0.21 & 0.1 & o & 0.1 & 0.29 & 0.55 & 0.7 & 0.51 & & & \\
\hline & Real mean & 234.91 & 248.06 & 250.78 & 244.58 & 287.84 & 305.96 & 321.21 & 305 & 290.71 & 326.22 & 362.76 & 326.57 & $* * *$ & $* * *$ & \\
\hline \multirow[t]{2}{*}{ Replacement rate (\%) } & Mean Z-score & -1.21 & -1.14 & -1.13 & -1.16 & 0.12 & 0.13 & 0.01 & 0.09 & 0.5 & 0.45 & 0.66 & 0.54 & & & \\
\hline & Real mean & 35.13 & 35.88 & 34.89 & 35.3 & 42.46 & 42.69 & 41.09 & 42.08 & 44.55 & 44.43 & 44.59 & 44.52 & $* * *$ & $* * *$ & \\
\hline \multirow[t]{2}{*}{ Max. UI duration (wk) } & Mean Z-score & -0.09 & -0.27 & -0.48 & -0.28 & 0.15 & 0.02 & 0.13 & 0.1 & -0.21 & 0.14 & 0.05 & -0.01 & & & \\
\hline & Real mean & 26 & 26 & 23.45 & $25 \cdot 15$ & 26.15 & 26 & 25.46 & 25.87 & 26.13 & 26. 18 & 26.15 & 26.15 & & & \\
\hline \multirow[t]{2}{*}{ Exhaustion rate (\%) } & Mean Z-score & 0.26 & 0.23 & 0.4 & 0.3 & o & -0.21 & -0.18 & -0.13 & -0.16 & 0.24 & 0.08 & 0.05 & & & \\
\hline & Real mean & 34.99 & 51.08 & 38.67 & 41.58 & 32.93 & 47.26 & 33.93 & 38.04 & 31.67 & 51. 11 & 36 & 39.6 & & & \\
\hline \multicolumn{17}{|l|}{ Contextual variables } \\
\hline Government ideology & Mean & 41.95 & 28.94 & 20.77 & 30.33 & 53.82 & 56.21 & 49.21 & 54.68 & 53.61 & 46.23 & 41.56 & 48.17 & * & & \\
\hline Unemployment rate & Mean & 4.43 & 9.36 & 6.11 & $7 \cdot 3$ & 4.64 & 8.55 & 5.41 & 6.8 & 3.99 & 7.77 & 5 & 6.1 & & & \\
\hline Observations & $\mathrm{n}$ & 9 & 9 & 9 & 9 & 27 & 27 & 27 & 27 & 15 & 15 & 15 & 15 & & & \\
\hline
\end{tabular}

Note: 1. "L," "U," and "B" refer to the limited protection approach, the unbalanced protection approach, and the balanced protection approach, respectively. 2. Scheffe's tests are cond ucted after the ANOVA tests to detennine whether there is a significant difference in the 1neans (colunıns (4), (8), and (12)) of the compared groups.

3. ${ }^{\star} \mathrm{p}<0.05,{ }^{* *} \mathrm{p}<0.01,{ }^{* * *} \mathrm{p}<0.001$ 


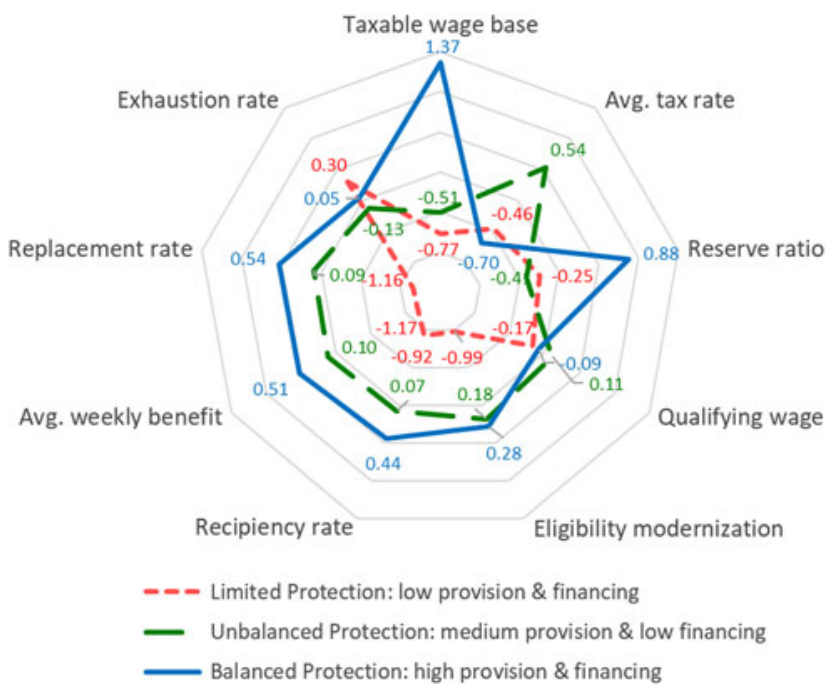

Figure 2. Standardized UI characteristics by approach.

over the study period and to conduct the mean difference tests as shown in columns (13)-(15). Figure 2 plots the three-year-average mean Z-score for each variable by cluster in a radar graph to visualize the characteristics across the three clusters.

As presented in Table 2 and Figure 2, the limited social protection approach (Cluster 1) stood out for its lower-than-the-national-average values for all policy characteristics, except for the highest mean exhaustion rate of $41.58 \%$ $(\bar{Z}=0.30)$. Notably, its mean eligibility modernization $(0.95, \bar{Z}=-0.995)$, mean recipiency rate $(22.84 \%, \bar{Z}=-0.92)$, mean average weekly benefit (244.58, $\bar{Z}=-1.17)$ and mean replacement rate $(35.3 \%, \bar{Z}=-1.16)$ were all well below the national averages. These nine states are largely concentrated in the South (see Figure 3), where people of colour make up a large share of the labour force and are overrepresented among the long-term unemployed (Krueger et al., 2014). Moreover, these states appeared to have significantly a higher score in conservative government ideology than their counterparts.

In contrast to the first cluster, cluster 2 and cluster 3 had values above the national average in social provision (e.g. eligibility modernization, recipiency rate, average weekly benefit, and replacement rate). However, the cluster 3 states had higher scores in these characteristics than the cluster 2 states. Notably, clusters 2 and 3 were distinct from one another in their UI financing characteristics, suggesting that the financing structure could mediate the level of social provision among the states with a more liberal government ideology. The radar graph (Figure 2) shows that the states in clusters 2 and 3 appeared to utilize different strategies of setting taxable wages and tax rates. Specifically, the states 


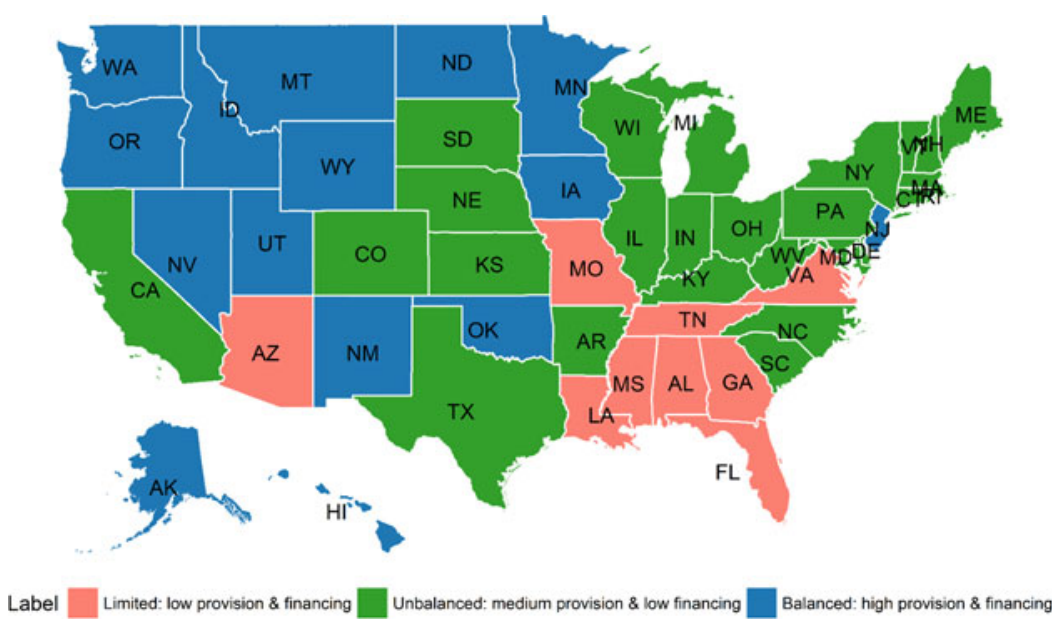

Figure 3. Map of state unemployment insurance approaches, 2007-2015.

in cluster 2 - which followed the unbalanced social protection approach tended to impose a high UI tax rate on employers, with the highest clusterlevel mean average tax rate of $3.08 \%(\bar{Z}=0.54)$. However, these states had lower-than-the-national-average taxable wages on average (mean $=11155.37$, $\bar{Z}=-0.51)$, and their mean UI reserve ratio was the lowest among the three clusters (mean $0.60, \bar{Z}=-0.41$ ). The twenty-seven states that represented the unbalanced social protection approach were concentrated in the Northeast and were sparsely dispersed across the Midwest, West, and South regions (Figure 3).

In contrast to cluster 2 , the states in cluster 3 - which followed the balanced social protection approach - scored the highest for the reserve ratio (mean $=1.74, \bar{Z}=0.88$ ). These states collected sufficient UI trust funds to support their UI systems by establishing higher taxable wage bases (mean $=28,187.18$, $\bar{Z}=1.37$ ). Figure 3 shows that the 15 states that follow this approach were concentrated in the West, with a few exceptions in other regions (Figure 3 ).

\section{Different changes in UI social protection and the underlying policy logic}

This section focuses on the trends in UI financing sufficiency (reserve ratio), programme accessibility (recipiency rate), and benefit adequacy (replacement rate and exhaustion rate) and discusses how these trends relate to policy design choices and underlying policy logic by approach. In general, the nationwide decreasing trends in UI financing sufficiency, programme accessibility and benefit adequacy indicate that there was little improvement in UI social protection in the U.S. from 2007 to 2015 . However, the magnitude of, and policy logic underlying, these changes varied by UI approach. 


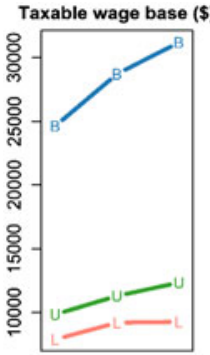

200720112015
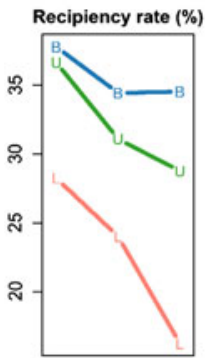

200720112015
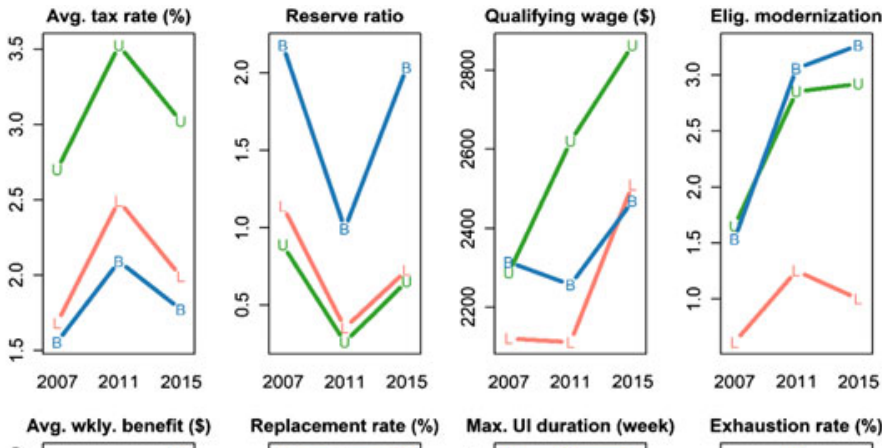

200720112015
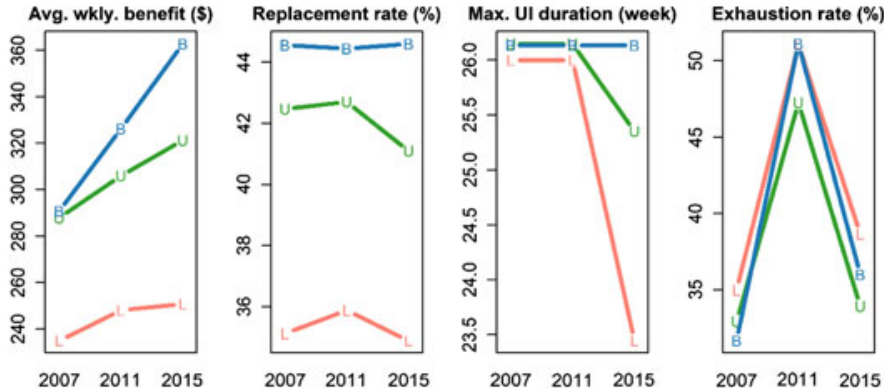

Label Limited: low provision \& financing

Unbalanced: medium provision \& low financing

Balanced: high provision \& financing

Figure 4. Trends in ten UI characteristics by approach, 2007-2015.

\section{Financing sufficiency}

UI's financing has a countercyclical function to reduce economic fluctuations. The UI tax revenue accumulated in economic booms serves as a "cushion" for economic downturns, when tax revenue decreases and expenditures on UI benefits increase. In response to the Great Recession, the state reserve ratio of the trust fund showed a decreasing trend at the national level from an average of 1.31 in 2007 to 0.49 in 2011 before increasing to 1.07 in 2015 (Table 1). Despite the increasing trend in the reserve ratio in the post-recessionary years, the level of the average state reserve ratio in 2015 (six years after the Great Recession) was still below the pre-recession level in 2007, with the largest decrease of 0.42 observed in the limited social protection approach and the smallest decrease of 0.14 observed in the balanced approach from 2007 to 2015 (Table 2 and Figure 4).

To analyse the relationships among financing sufficiency, financing design elements, and the underlying policy logic, model 1 considers the macroeconomic condition, political ideology, average tax rate, and taxable wage base as predictors of the reserve ratio while controlling for the recipiency rate and replacement rate. The results of the regression provided evidence of economic stabilization across the three approaches (Table 3, columns (1)-(3)). The observed changes in the state reserve ratios were sufficiently explained by the state macroeconomic 
TABLE 3. Panel regression models with state fixed effects

\begin{tabular}{|c|c|c|c|c|c|c|c|c|c|c|c|c|c|c|c|}
\hline & \multicolumn{3}{|c|}{ Model 1} & \multicolumn{3}{|c|}{ Model 2} & \multicolumn{3}{|c|}{ Model 3} & \multicolumn{3}{|c|}{ Model 4} & \multicolumn{3}{|c|}{ Model 5} \\
\hline & \multicolumn{3}{|c|}{ Reserve ratio } & \multicolumn{3}{|c|}{ Average tax rate } & \multicolumn{3}{|c|}{ Recipienc:y rate } & \multicolumn{3}{|c|}{ Replacement rate } & \multicolumn{3}{|c|}{ Exh austion rate } \\
\hline & Limited & Unbalanced & Balanced & Limited & Unbalanced & Balanced & Limited & Unbalanced & Balanced & Limited & Unbalanced & Balanced & Limited & Unbalanced & Balanced \\
\hline & (1) & (2) & (3) & (4) & (5) & (6) & (7) & (8) & (9) & (10) & (11) & (12) & (13) & (14) & (15) \\
\hline Gov. ideology & $\begin{array}{l}0.010^{*} \\
(0.00)\end{array}$ & $\begin{array}{l}-0.002 \\
(0.00)\end{array}$ & $\begin{array}{l}0.005 \\
(0.01)\end{array}$ & $\begin{array}{l}0.012 \\
(0.01)\end{array}$ & $\begin{array}{l}0.002 \\
(0.00)\end{array}$ & $\begin{array}{l}0.003 \\
(0.00)\end{array}$ & $\begin{array}{l}0.189^{*} \\
(0.08)\end{array}$ & $\begin{array}{l}\text { o. } 117^{* *} \\
(0.04)\end{array}$ & $\begin{array}{l}0.016 \\
(0.09)\end{array}$ & $\begin{array}{l}0.061^{*} \\
(0.02)\end{array}$ & $\begin{array}{c}-0.022 \\
(0.02)\end{array}$ & $\begin{array}{l}-0.018 \\
(0.02)\end{array}$ & $\begin{array}{c}0.132^{* *} \\
(0.04)\end{array}$ & $\begin{array}{l}-0.027 \\
(0.03)\end{array}$ & $\begin{array}{l}-0.005 \\
(0.05)\end{array}$ \\
\hline Unemploy. rate & $\begin{array}{c}-0.122^{* * *} \\
(0.02)\end{array}$ & $\begin{array}{c}-0.126^{* * *} \\
(0.03)\end{array}$ & $\begin{array}{c}-0.299^{* * *} \\
(0.05)\end{array}$ & $\begin{array}{l}0.144 \\
(0.07)\end{array}$ & $\begin{array}{c}0.188^{* * *} \\
(0.02)\end{array}$ & $\begin{array}{l}0.057 \\
(0.05)\end{array}$ & $\begin{array}{l}-1.461 \\
(\mathrm{I} .04)\end{array}$ & $\begin{array}{c}-1.858^{* * *} \\
(0.29)\end{array}$ & $\begin{array}{c}-1.687 \\
(0.98)\end{array}$ & $\begin{array}{l}-0.459 \\
(0.29)\end{array}$ & $\begin{array}{c}0.408^{* *} \\
(0.14)\end{array}$ & $\begin{array}{c}-0.418^{*} \\
(0.19)\end{array}$ & $\begin{array}{c}3.175^{* * *} \\
(0.37)\end{array}$ & $\begin{array}{c}3.302^{* * *} \\
(0.37)\end{array}$ & $\begin{array}{c}3.328^{* * *} \\
(0.45)\end{array}$ \\
\hline Avg. tax rate & $\begin{array}{c}-0.069 \\
(0.10)\end{array}$ & $\begin{array}{l}-0.065 \\
(0.08)\end{array}$ & $\begin{array}{l}0.296 \\
(0.25)\end{array}$ & & & & & & & & & & & & \\
\hline Taxable wage base & $\begin{array}{l}-0.000 \\
(0.00)\end{array}$ & $\begin{array}{c}-0.000 \\
(0.00)\end{array}$ & $\begin{array}{l}0.000 \\
(0.00)\end{array}$ & $\begin{array}{c}-0.000 \\
(0.00)\end{array}$ & $\begin{array}{c}-0.000 \\
(0.00)\end{array}$ & $\begin{array}{l}0.000 \\
(0.00)\end{array}$ & & & & & & & & & \\
\hline Recipiency rate & $\begin{array}{l}-0.019 \\
(0.01)\end{array}$ & $\begin{array}{l}-0.018 \\
(0.01)\end{array}$ & $\begin{array}{c}-0.055^{*} \\
(0.02)\end{array}$ & $\begin{array}{c}-0.002 \\
(0.02)\end{array}$ & $\begin{array}{l}0.021 \\
(0.01)\end{array}$ & $\begin{array}{l}0.001 \\
(0.01)\end{array}$ & & & & $\begin{array}{l}0.038 \\
(0.03)\end{array}$ & $\begin{array}{l}0.199^{* *} \\
(0.07)\end{array}$ & $\begin{array}{l}0.059 \\
(0.06)\end{array}$ & $\begin{array}{l}0.327 \\
(0.15)\end{array}$ & $\begin{array}{c}0.654^{* * *} \\
(0.11)\end{array}$ & $\begin{array}{l}0.289 \\
(0.24)\end{array}$ \\
\hline Replacement rate & $\begin{array}{l}0.013 \\
(0.03)\end{array}$ & $\begin{array}{l}0.007 \\
(0.02)\end{array}$ & $\begin{array}{l}-0.029 \\
(0.05)\end{array}$ & $\begin{array}{l}0.005 \\
(0.04)\end{array}$ & $\begin{array}{c}-0.021 \\
(0.02)\end{array}$ & $\begin{array}{c}-0.047 \\
(0.03)\end{array}$ & $\begin{array}{l}-0.641 \\
(0.91)\end{array}$ & $\begin{array}{l}0.620^{*} \\
(0.25)\end{array}$ & $\begin{array}{l}2.071^{*} \\
(0.80)\end{array}$ & & & & $\begin{array}{l}-0.546 \\
(0.43)\end{array}$ & $\begin{array}{l}0.096 \\
(0.30)\end{array}$ & $\begin{array}{l}1.333^{* *} \\
(0.41)\end{array}$ \\
\hline Reserve ratio & & & & $\begin{array}{c}-0.715 \\
(0.38)\end{array}$ & $\begin{array}{c}-0.496^{* *} \\
(0.15)\end{array}$ & $\begin{array}{c}-0.500^{* * *} \\
(0.10)\end{array}$ & $\begin{array}{l}-4.671 \\
(4.01)\end{array}$ & $\begin{array}{l}0.957 \\
(1.59)\end{array}$ & $\begin{array}{c}-1.833 \\
(2.48)\end{array}$ & $\begin{array}{c}-4.226^{*} \\
(1.80)\end{array}$ & $\begin{array}{l}0.695 \\
(0.58)\end{array}$ & $\begin{array}{l}-0.218 \\
(0.46)\end{array}$ & $\begin{array}{l}2.903 \\
(2.85)\end{array}$ & $\begin{array}{l}-1.079 \\
(1.46)\end{array}$ & $\begin{array}{l}-0.280 \\
(1.48)\end{array}$ \\
\hline $\begin{array}{l}\text { Interstate } \\
\quad \text { competition }\end{array}$ & & & & $\begin{array}{l}0.935 \\
(0.49)\end{array}$ & $\begin{array}{l}1.218^{* *} \\
(0.36)\end{array}$ & $\begin{array}{l}0.863^{* *} \\
(0.22)\end{array}$ & & & & $\begin{array}{c}-19.287^{*} \\
(6.34)\end{array}$ & $\begin{array}{c}18.164^{* *} \\
(4.90)\end{array}$ & $\begin{array}{c}-2.013 \\
(5.53)\end{array}$ & & & \\
\hline Qualifying wage & & & & & & & $\begin{array}{c}-0.005^{* *} \\
(0.00)\end{array}$ & $\begin{array}{c}-0.002^{*} \\
(0.00)\end{array}$ & $\begin{array}{l}0.000 \\
(0.00)\end{array}$ & & & & & & \\
\hline $\begin{array}{l}\text { Elig. } \\
\text { modernization }\end{array}$ & & & & & & & $\begin{array}{l}-1.417 \\
(1.04)\end{array}$ & $\begin{array}{c}-1.177 \\
(0.86)\end{array}$ & $\begin{array}{l}-2.243 \\
(1.23)\end{array}$ & & & & & & \\
\hline Avg. wkly. benefit & & & & & & & & & & $\begin{array}{l}0.041 \\
(0.03)\end{array}$ & $\begin{array}{l}0.019 \\
(0.02)\end{array}$ & $\begin{array}{l}0.012 \\
(0.01)\end{array}$ & & & \\
\hline Max. duration & & & & & & & $\begin{array}{l}1.181^{\star} \\
(0.43)\end{array}$ & $\begin{array}{l}1.361^{\star} \\
(0.63)\end{array}$ & $\begin{array}{c}0.000 \\
(.)\end{array}$ & & & & $\begin{array}{c}-0.644 \\
(0.33)\end{array}$ & $\begin{array}{c}-1.773^{\star *} \\
(0.50)\end{array}$ & $\begin{array}{c}0.000 \\
(.)\end{array}$ \\
\hline
\end{tabular}

Note: 1. Standard errors are shown in parentheses.

2. ${ }^{*} \mathrm{p}<0.05,{ }^{* *} \mathrm{p}<0.01,{ }^{* * *} \mathrm{p}<0.001$ 
condition over the study period, with the largest effect observed in the states that follow the balanced social protection approach $(-0.30, \mathrm{p}<.001)$ and the smallest effect observed in the states that follow the limited social protection approach $(-0.12, \mathrm{p}<.001)$. In addition to the macroeconomic factor, the increasing conservative government ideology $(0.01, \mathrm{p}<.05)$ explained the decreasing financing sufficiency among the states that adopted the limited social protection approach, while this association was not evident in their counterparts.

Previous research has suggested that the UI tax rate drives the long-term erosion of UI finances (Hertel-Fernandez, 2013) and that interstate competition affects how states set their tax rates (Bassi and McMurrer, 1998). Model 2 tests the effect of interstate competition on the state average tax rate. In contrast to the interstate competition argument, I found that the states that had an average tax rate higher than the average tax rate of its neighbouring states tended to have a higher average tax rate in the following year. This finding was only evident with the unbalanced social protection approach and the balanced social protection approach (the estimated parameters of interstate competition were $1.22, \mathrm{p}<.01$ and $0.86, \mathrm{p}<.01$, respectively) but was not evident with the limited social protection approach (Table 3 , Columns (4)-(6)).

\section{Programme accessibility}

Over the study period, the average state UI recipiency rate decreased at the national level from $35.52 \%$ in 2007 to $30.84 \%$ in 2011 and $28.26 \%$ in 2015 (Table 1). On average, the states that adopted the balanced social protection approach experienced a milder decreasing trend in the recipiency rate, while the states that adopted the other two approaches experienced sharper decreasing trends (Figure 4).

To analyse the relationships among programme accessibility, eligibility design elements, and the underlying policy logic, model 3 considers the macroeconomic condition, political ideology, qualifying wage, eligibility modernization, and maximum duration as predictors of the recipiency rate while controlling for the reserve ratio and replacement rate. The results revealed that increasing the qualifying wage, reducing the maximum benefit duration, and increasing the conservative political ideology significantly predicted a decreasing recipiency rate among the states that adopted the limited or unbalanced social protection approaches (see Table 3 , columns (7)-(9); the estimates of government ideology were $0.19, \mathrm{p}<.05$ and $0.12, \mathrm{p}<.01$; the estimates of the qualifying wage were $-0.005, \mathrm{p}<.01$ and $-0.002, \mathrm{p}<.05$; and the estimates of the maximum benefit duration were $1.18, \mathrm{p}<.05$ and $1.34, \mathrm{p}<.05)$. These findings indicated that state policymakers (particularly those in states that followed the limited and unbalanced social protection approaches) made inadequate or uncoordinated UI policy decisions to maintain the level of programme accessibility, although many programmes received federal incentive funding to expand 
their eligibility rules under the UIMA. In the context of an increasing conservative political ideology, state policy makers tended to impose stricter job search requirements to avoid work disincentives during the post-recessionary years. The logic of work disincentives was most evident in the states that took the limited social protection approach: on average, these states required three job search activities per week in 2015, which was one more activity than their counterparts (U.S. Department of Labor, 2015b).

\section{Benefit adequacy}

Regarding the trend in benefit adequacy, the mean replacement rate remained at approximately the same level of $44.5 \%$ in the states that adopted the balanced social protection approach, while the replacement rate slightly decreased in the states that adopted the limited or unbalanced social protection approaches (Figure 4). Researchers have observed that states made various policy decisions to reduce UI benefit levels, including changing the formula for calculating benefits, changing the period during which benefits were calculated, legislating new maximum benefit levels, and postponing automatic benefit adjustments (Smith and Wenger, 2013).

To analyse the relationships among benefit adequacy, the benefit design elements, and the underlying policy logic, model 4 considers the macroeconomic condition, political ideology, average weekly benefit, and interstate competition as predictors of the replacement rate while controlling for the reserve ratio and recipiency rate. Table 3 (columns (10)-(12)) show that an increasing conservative government ideology $(0.06, \mathrm{p}<.05)$ and interstate competition $(-19.29, \mathrm{p}<.05)$ explained the decreasing trend in the replacement rate among the states that adopted the limited social protection approach. In contrast, the decreasing replacement rate among the states that adopted the unbalanced social protection approach might be explained by the path dependence of social protection as follows: the states that had a less generous provision relative to their peers were more likely to reduce the level of generosity in the following year (18.16, $\mathrm{p}<.01)$.

Finally, the average exhaustion rate increased at the national level from $33 \%$ in 2007 to $49 \%$ in 2011 and then decreased to $35 \%$ in 2015 (Table 1). The states that adopted the balanced social protection approach experienced the highest exhaustion rate of $51 \%$ during the bad economic period.

To explore the possible explanations of the changing exhaustion rate, Model 5 considers the macroeconomic condition, political ideology, and maximum benefit duration as predictors of the exhaustion rate while controlling for the reserve ratio, recipiency rate, and replacement rate. Table 3 (columns (13)-(15)) shows that an increasing unemployment rate was a strong predictor of an increasing exhaustion rate across the three approaches $(3.18, \mathrm{p}<.001$, $3.30, \mathrm{p}<.001$, and $3.33, \mathrm{p}<.001$ ). In addition to the macroeconomic factor, 
increasing benefit generosity $(1.33, \mathrm{p}<.01)$ also explained the increasing exhaustion rate in the states that adopted the balanced social protection approach after controlling for the other variables. This finding suggests that the states that took the balanced social protection approach might weigh the logic of social protection over the logic of work disincentive - they generally supported workers to maximize their benefits and to take a longer time to return to the workforce by providing more generous benefits, particularly when the job market was still difficult in the wake of the Great Recession. In contrast, the decreasing maximum benefit duration $(-1.77, \mathrm{p}<.01)$ significantly explained the increasing exhaustion rate for the states that took the unbalanced social protection approach, whose UI systems were less committed to the logic of social protection and were more responsive to the increasing conservative government ideology as the earlier discussion on the decreasing trend in UI recipients indicates.

\section{Conclusion}

Turbulent social and economic circumstances during the Great Recession and its aftermath challenged the UI systems in many industrialized countries. Increasing attention has been paid to the US federal-state UI system and its implications for a possible Europe-wide UI system. In response to the Great Recession and its prolonged aftermath, the American UI system has undergone many changes in financing and provision arrangements. The substantial cross-state variation in UI designs and performances provides an empirical ground for the identification of different UI approaches to social protection. In this paper, I define UI approaches to social protection as ways to design and implement UI that have interrelated elements working as unified systems to achieve social protection.

Using the multidimensional policy indicators of 51 states' UI programmes over a period from 2007 to 2015 , I identify three distinct UI approaches to social protection under the American federal-state UI system. First, the limited social protection approach features a meagre social provision with a weak financing structure. The states that adopted this protection approach tended to have a higher conservative ideology than their counterparts. The policy choices made by these states reflected a low commitment to social protection (e.g. low financing sufficiency, programme accessibility, and benefit adequacy), weak countercyclical responses in terms of financing and provisions, and a strong emphasis on work disincentives (e.g. stricter job search requirements and shorter benefit durations) in an increasingly conservative political setting. Moreover, these states appeared to follow the logic of interstate competition by reducing the benefit level when their benefits were more generous than their neighbouring states. Second, the unbalanced social protection approach features a medium social provision with low financing sufficiency. The policy decisions made by the states 
that followed the unbalanced social protection approach reflected a mixture of policy logic, including social protection, market stabilization, and work disincentives, in response to both the prolonged economic recession and an increasing conservative government ideology. Competing policy logic resulted in uncoordinated policy responses that failed to achieve a higher level of social protection. For example, on the one hand, many states modernized their eligibility rules, but, on the other hand, these states reduced the benefit levels and duration. In contrast to the states adopting the limited social protection approach, the states adopting the unbalanced social protection approach did not reduce their benefit levels and tax rates to maintain their economic competitive advantages through an interstate competition mechanism. In contrast, their changes in the benefit levels and tax rates were consistent with their past policy preferences relative to their neighbouring states' efforts through a path dependence mechanism. Third, the balanced social protection approach features the most inclusive and adequate social provision with strong financing arrangements. The policy changes of the states that followed the balanced social protection approach were strongly driven by the logic of social protection and the logic of market stabilization in response to the needs of unemployed workers and the economic cycle. Compared with their counterparts, these states tended to improve or maintain a reasonable level of social protection during and after the Great Recession. However, fewer than only one-third of the states represented the balanced social protection approach. That is, most American workers are residents of states with frail UI systems and declining social protection. The overall downward social protection signals that the American UI system is under-prepared for the next economic recession, thereby exposing unemployed workers to the risk of economic insecurity.

The unequal and declining social protection of the American UI system underscores the importance of the federal role in mandating or facilitating reforms. A stronger federal role in social protection could avoid the reluctance of individual states to provide adequate and responsive unemployment protection due to their political and economic preferences (Vroman, 2012; West et al., 2016). For example, to strengthen financing sufficiency, the federal government could increase the minimum taxable wage requirement and annually adjust it for inflation. To improve programme accessibility, the federal government could continue to encourage states to modernize their UI eligibility rules to keep pace with the changing labour force. To ensure benefit adequacy, a federal mandate for a uniform maximum duration of at least 26 weeks for regular state benefits would make the previously universal up-to-26-weeks benefit available to all UI claimants. In addition, states could consider indexing the weekly benefits amount to prevent eroding the real value.

The US experience also provides insight into possible institutional designs and their rationales for a supranational EUBS. Despite existing proposals that 
weigh differently on the rationales for macroeconomic stabilization, moral hazard, and social protection/solidarity, their design features inevitably would need certain common minimum standards to harmonize current national unemployment benefit schemes (Andor, 2016; Beblavý et al., 2015). The framework for studying UI approaches and the cluster analysis performed in this paper are informative for future researchers identifying the distinct UI approaches adopted by European countries and setting reasonable common criteria for basic social protection under a EUBS, which could have the potential of strengthening the social solidarity of European citizens.

\section{Acknowledgements}

I would like to thank Dr. Marcia Meyers, Dr. Jennifer Romich, Dr. Melissa Martinson, and the anonymous reviewers who provided feedback on early drafts of the paper.

\section{Financial support}

This research was funded by the Individual Research Grants for Graduate Students by the Harry Bridges Center for Labor Studies. Findings and conclusions are those of the author and do not necessarily reflect the views of the supporting agency.

\section{Notes}

1 A state programme that adopted an alternative base period scored a 2, a programme that adopted a part-time provision was scored a 1, and a programme that adopted any of the following alternative reasons for leaving a job was scored a 0.25 : domestic violence, spouse relocation, illness and disability, and other reasons. These different weights reflected the principles of the UIM funding distribution (U.S. Department of Labor, 2011).

2 Three points in time (2007, 2011, and 2015) were used to describe the state UI characteristics over the study period. To reduce the possible measuring errors and year-to-year fluctuations, I averaged the 2006-2007 data, 2010-2011 data, and 2014-2015 data to represent the three points in time. For simplification, the 2007,2011 and 2015 data are used to refer to the respective two-year average data in the results section.

3 To increase the efficiency of a model-based cluster analysis by reducing the number of variables (Fraley et al., 2012), I calculated the coefficient of variation (COV), which is the ratio of the standard deviation of a given variable to its mean. The smallest COV of the maximum UI duration variables suggested little dispersion of this variable among states (Table 1). The duration variables were then dropped in the cluster analysis but were included in the follow-up descriptive analysis.

4 The BIC is computed over different models to inform the optimal number of clusters and the types of models that most closely fit the observed data (Fraley and Raftery, 1998; Everitt and Hothorn, 2011). A larger BIC provides stronger evidence of a model fit (Kass and Raftery, 1995; Fraley et al., 2012).

5 Only Alaska, New Jersey, and Pennsylvania levy UI taxes on both employers and employees. 


\section{References}

Arcanjo, M. (2012), 'Unemployment insurance reform-1991-2006: a new balance between rights and obligations in France, Germany, Portugal and Spain', Social Policy \& Administration, 46: 1, 1-20.

Ahlquist, J. S. and Breunig, C. (2012), 'Model-based clustering and typologies in the social sciences', Political Analysis, 20: 1, 92-112.

Allan, J. P. and Scruggs, L. (2004), 'Political partisanship and welfare state reform in advanced industrial societies', American Journal of Political Science, 48: 3, 496-512.

Esping-Andersen, G. (1990), The three worlds of welfare capitalism. Cambridge, UK: Polity Press and Princeton, NJ: Princeton University Press.

Andor, L. (2016), 'Towards shared unemployment insurance in the euro area', IZA Journal of European Labor Studies, 5: 10, 1-15.

Bassi, L. J. and McMurrer, D. P. (1998), 'Unemployment Insurance in a federal System: A Race to the bottom', Essays on Interstate Competition in the Unemployment Insurance System (Unemployment Insurance Occasional Paper 98-5). Washington, D.C.: U.S. Unemployment Insurance Service.

Beblavý, M., Marconi, G. and Maselli, I. (2015), 'A European Unemployment Benefits Scheme: The rationale and the challenges ahead'. Centre for European Policy Studies Special Report, (No.119 / September 2015). Brussels: Centre for European Policy Studies.

Berry, W. D., Fording, R. D., Ringquist, E.J., Hanson, R. L. and Klarner, C. (2010), 'Measuring Citizen and Government Ideology in the American States: A Re-appraisal', State Politics and Policy Quarterly, 10: 117-35.

Bivens, J., Smith, J. and Wilson, V. (2014), 'State cuts to jobless benefits did not help workers or taxpayers', Economic Policy Institute Briefing Paper, 380, Washington, D.C.: Economic Policy Institute.

Chang, Yu-Ling. (2015), 'Re-examining the US social safety net for working-age families: Lessons from the Great Recession and its aftermath', Journal of Policy Practice, 14: 2, 139-161.

Davis, L. E., Konstantinidis, C. and Tripodis, Y. (2015), 'A proposal for a federalized Unemployment Insurance mechanism for Europe', Workingpaper Series, 402. Boston, Massachusetts: Political Economy Research Institute, University of Massachusetts Amherst.

Esser, I., Ferrarini, T., Nelson, K., Palme, J. and Sjöberg, O. (2013), Unemployment Benefits in EU Member States, Belgium: European Commission, Employment, Social Affairs \& Inclusion.

Everitt, B. and Hothorn, T. (2011), An Introduction to Applied Multivariate Analysis with R, New York: Springer Science \& Business Media.

Fraley, C and Raftery, A. E. (1998), 'How many clusters? which clustering method? answers via model-based cluster analysis', The Computer Journal, 41: 8, 578-588.

Fraley, C., Raftery, A. E. and Scrucca, L. (2012), mclust Version 4 for R: Normal Mixture Modeling for Model-Based Clustering, Classification, and Density Estimation. Seattle, Washington: Department of Statistics, University of Washington.

Fossati, F. (2018), 'Who wants demanding active labour market policies? Public attitudes towards policies that put pressure on the unemployed', Journal of Social Policy, 47: 1, 77-97.

Gallie, D. and Paugam, S. (2000), Welfare Regimes and the Experience of Unemployment in Europe (pp. 1-22), Oxford, UK: Oxford University Press.

Gould-Werth, A. and Shaefer, H. L. (2013), 'Do alternative base periods increase Unemployment Insurance receipt among low-educated unemployed workers?' Journal of Policy Analysis and Management, 32: 4, 835-852.

Henchman, J. D. (2011), 'Unemployment Insurance taxes: Options for program design and insolvent trust funds', Tax Foundation, Background Paper, 61, Washington, D.C.: Tax Foundation.

Hertel-Fernandez, A. (2013), 'Dismantling policy through fiscal constriction: Examining the erosion in state Unemployment Insurance finances', Social Service Review, 87: 3, 438-476. 
Ingram, H. M., Schneider, A. L. and deLeon, P. (2007), 'Social construction and policy design', 93-126 in Theories of the Policy Process, edited by Sabatier, P. A. Boulder, Colorado: Westview Press.

Kass, R. E. and Raftery, A. E. (1995), 'Bayes factors', Journal of the American Statistical Association, 90: 430, 773-795.

Kimball, W. and McHugh, R. (2015), 'How low can we go? State Unemployment Insurance programs exclude record numbers of jobless workers', Economic Policy Institute Briefing Paper, 392, Washington, D.C.: Economic Policy Institute.

Koreh, M. (2017), 'The political economy of social insurance: Towards a fiscal-centred framework', Social Policy \& Administration, 51:1, 114-132.

Krueger, A. B., Cramer, J. and Cho, D. (2014), 'Are the long-term unemployed on the margins of the labor market?' Brookings Papers on Economic Activity, 229-28o, Washington, D.C.: Brookings Institution.

Lenaerts, K., Paquier, F. and Simonetta, S. (2017), 'Unemployment Insurance in America: A model for Europe?' CEPS Policy Insights No 2017/23, June 2017. Brussels: Center for European Policy Studies.

Lindner, S and Nichols, A. (2012), 'How do Unemployment Insurance modernization laws affect the number and composition of eligible workers?' Washington, D.C.: The Urban Institute.

O'Connor, B. (2004), A political history of the American welfare system: when ideas have consequences. Lanham, MD: Rowman \& Littlefield Publishing Group, Inc.

OECD. (2017), Benefits and Wages: Statistics. Retrieved from: http://www.oecd.org/els/ benefits-and-wages-statistics.htm

O'Leary, C. J. and Barnow, S. (2016), 'Lessons from the American federal-state Unemployment Insurance system for a European Unemployment Benefits System', Upjohn Institute Working Paper 16-264. Kalamazoo, MI: W.E. Upjohn Institute.

Orloff, A. S. and Skocpol, T. (1984), 'Why not equal protection? Explaining the politics of public social spending in Britain, 1900-1911, and the United States, 1880s-1920', American Sociological Review, 49: 6, 726-750.

Ozkan, U. R. (2014), 'Comparing formal Unemployment Compensation systems in 15 OECD countries', Social Policy \& Administration, 48: 1, 44-66.

Pierson, P. (1995), 'Fragmented welfare states: Federal institutions and the development of social policy', Governance, 8: 4, 449-478.

Pierson, P. (2000), 'Increasing returns, path dependence, and the study of politics', American Political Science Review, 94:2, 251-267.

Schneider, A. L and Ingram, H. M. (1988), 'Systematically pinching ideas: A comparative approach to policy design', Journal of Public Policy, 8: 1, 61-80.

Schneider, A. L. and Ingram, H. M. (1997), Policy Design for Democracy, Lawrence, Kansas: University Press of Kansas.

Scruggs, L. A. and Allan, J. P. (2008), 'Social stratification and welfare regimes for the twenty-first century: Revisiting the three worlds of welfare capitalism', World Politics, 6o: 4, 642-664.

Shaefer, H. L. (2010), 'Identifying key barriers to Unemployment Insurance for disadvantaged workers in the United States', Journal of Social Policy, 39: 3, 439-46o.

Shaefer, H. L. and Wu, L. (2011), 'Unemployment Insurance and low-educated, single, working mothers before and after welfare reform', Social Service Review, 85: 2, 205-228.

Shahidi, F. V. (2015), 'Welfare capitalism in crisis: A qualitative comparative analysis of labour market policy responses to the Great Recession', Journal of Social Policy, 44: 4, 659-686.

Sinfield, A. (2018), 'Fiscal welfare and its contribution to inequality', in Social Policy Review 30 : Analysis and debate in social policy, 2018, edited by Needham, C., Heins, E. and Rees, J. Bristol, UK: Policy Press/Social Policy Association.

Smith, D. L. and Wenger, J. B. (2013), 'State Unemployment Insurance trust solvency and benefit generosity', Journal of Policy Analysis and Management, 32: 3, 536-553.

Tatsiramos, K. and Ours, J. C. (2014), 'Labor market effects of Unemployment Insurance design', Journal of Economic Surveys, 28: 2, 284-311. 
U.S. Department of Labor. (2011), 'Unemployment Insurance modernization incentive payment state certifications', Washington, D.C.: U.S. Department of Labor, Employment \& Training Administration.

U.S. Department of Labor. (2015a), 'Unemployment Insurance data summary: 4th quarter 2015', Washington, D.C.: U.S. Department of Labor, Employment \& Training Administration.

U.S. Department of Labor. (2015b), 'Comparison of State Unemployment Laws, 2015', Washington, D.C.: U.S. Department of Labor, Employment \& Training Administration.

U.S. Department of Labor. (2015c), 'UI Replacement Rates Report', Washington, D.C.: U.S. Department of Labor, Employment \& Training Administration.

U.S. Department of Labor. (2015d), 'Significant provisions of state UI laws, Jan 2015', Washington, D.C.: U.S. Department of Labor, Employment \& Training Administration.

Vroman, W. and Brusentsev, V. (2005), Unemployment Compensation Throughout the World: A Comparative Analysis, Kalamazoo, MI: W.E. Upjohn Institute.

Vroman, W. (2010), 'The role of Unemployment Insurance as an automatic stabilizer during a Recession.' Columbia, Maryland: IMPAQ International.

Vroman, W. (2012), 'Financing Unemployment Insurance after the Great Recession', Unemployment and Recovery Project Brief \# 07. Washington, D.C.: The Urban Institute.

West, R., Dutta-Gupta, I., Grant, K. and Boteach, M. (2016), 'Where states are and where they should be on unemployment protections', Washington, D.C.: Center for American Progress.

Whittaker, J. M. and Isaacs, K. P. (2012), Unemployment Insurance: Programs and Benefits, Washington, D.C.: Congressional Research Service. 